\title{
Distinct sputum cytokine profiles in cystic fibrosis and other chronic inflammatory airway disease
}

\author{
E. Osika*, J-M. Cavaillon**, K. Chadelat*, M. Boule*, C. Fitting**, G. Tournier*, A. Clement*
}

Distinct sputum cytokine profiles in cystic fibrosis and other chronic inflammatory airway disease. E. Osika, J-M. Cavaillon, K. Chadelat, M. Boule, C. Fitting, G. Tournier, A. Clement. (C) ERS Journals Ltd 1999.

ABSTRACT: The dominant role of inflammation in airways disease progression in cystic fibrosis (CF) is now well established and, based on recent findings, the possibility of an inappropriate inflammatory response in the lung of patients with $\mathrm{CF}$ has emerged. In order to characterize this response, the aim of the present work was to evaluate the levels of a number of pro- and anti-inflammatory cytokines in the sputum of CF children and to compare these levels to those observed in the sputum from non-CF children with diffuse bronchiectasis (DB).

Three groups of patients were investigated: a group of $25 \mathrm{CF}$ children (mean age: 12.2 yrs), a group of 10 non-CF children with DB (mean age $11.5 \mathrm{yrs}$ ), and a group of five healthy young adults (mean age 24 yrs).

Elevated concentrations of pro-inflammatory cytokines, tumour necrosis factor (TNF)- $\alpha$, interleukin (IL)-1 $\beta$ and IL-8 were found in children with CF and in non-CF children with DB, with significantly higher concentrations of IL-1 $\beta$ in CF children. Analysis of the natural anti-inflammatory cytokine IL-1 receptor antagonist (IL-1ra) and type II TNF soluble receptor (sTNFRII) concentrations showed distinct patterns, with elevated levels of both inhibitors in CF patients, whereas only sTNFRII was found to be increased in non-CF children with DB. IL-10 data indicated low concentrations in the CF group. In all CF children, the concentrations of IL-6 in the airways were extremely low, independent of the clinical, bacteriological or functional status. By contrast, significantly increased IL-6 levels were found in non-CF children with DB.

These results document distinct cytokine profiles in cystic fibrosis patients and noncystic fibrosis patients. They also suggest that impairment of interleukin-6 expression may represent an important component of the excessive inflammatory response observed in cystic fibrosis.

Eur Respir J 1999; 14: 339-346.
*Dept de Pneumologie PediatriqueINSERM U515, Hôpital Trousseau, and **Unité d'immuno-allergie, Institut Pasteur, Paris, France.

Correspondence: A. Clement

Dept de Pneumologie Pediatrique

Hôpital Trousseau

26, Ave Dr Netter

75012 Paris

France

Fax: 330144736725

Keywords: Children

cystic fibrosis

cytokines

inflammation

sputum

Received: August 211998

Accepted after revision March 31999

This work was supported by grants from the Association Française de Lutte contre la Mucoviscidose(AFLMR98013), the Assistance Publique-Hopitaux de Paris (CRC 980703), the Association Claude Bernard, the Fondation Lancardis and the Chancellerie des Universites de Paris (Legs Poix to A.C.).
Cystic fibrosis (CF) is the most frequent lethal autosomal recessive hereditary disorder in Caucasian populations and is caused by mutations in the CF transmembrane conductance regulator (CFTR) gene whose product functions as a cyclic adenosine monophosphate-regulated chloride channel [1]. Many organs are involved but the lung represents the major target, and the pulmonary manifestations are the most common life-threatening aspects of the disease. Mutations in the CFTR gene lead to altered CFTR function in the airway epithelium, causing production of abnormally thick secretions. Mucus obstruction of small airways is associated with the development of chronic inflammation and infection. Progressively, the airways are irreversibly damaged and bronchiectatic cysts develop. The bronchioles become stenosed and obliterated, and the pathological processes extend to the peribronchiolar alveolar structures, causing fibrosis and alveolar destruction [2].

If a sequence of events leading from failure of lung defence in $\mathrm{CF}$ patients with infection, to a marked inflammatory response, is a logical concept, several recent studies support the view that inflammation may occur independently of infection, at least in the initial stage.
Controlled analyses of bronchoalveolar lavage (BAL) fluid from infants with $\mathrm{CF}$ have documented the presence of increased inflammatory parameters including neutrophil counts, activity of free neutrophil elastase and interleukin (IL)-8 levels. Surprisingly, these markers were found even in the absence of CF-related pathogens [3-5]. From these data, it can be proposed that, in CF patients, endogenous signal(s) may be generated, leading to an intense inflammatory response with the production of factors which could damage the airway surface and favour infection and bacterial colonization. These signals may be directly linked to the abnormal CFTR and may be associated with a dysregulated inflammatory response [6].

The inflammatory response is the result of a complex balance between pro-inflammatory and anti-inflammatory mediators. Several studies in the literature have documented high levels of several cytokines, mainly IL-1 $\beta$, IL8 and tumour necrosis factor (TNF)- $\alpha$ in CF airways $[2,3$, $5,7-15]$. In order to determine whether this intense cytokine release may be associated with an imbalance between pro-inflammatory and anti-inflammatory molecules and, therefore, with defective homeostasis, the levels of pro- and 
anti-inflammatory cytokines in the sputum of children with $\mathrm{CF}$ at various stages of the disease were evaluated. The molecules studied in this work included: the pro-inflammatory cytokines IL- $1 \beta$, TNF- $\alpha$, and IL- 8 ; the cytokine antagonists and inhibitors IL-1 receptor antagonist (IL-1 ra) and soluble TNF receptor II (sTNFRII); and the antiinflammatory molecules IL-10 and IL-6. To address the question of an inappropriate inflammatory response in the lung of patients with $\mathrm{CF}$, the cytokine levels in sputum samples from $\mathrm{CF}$ children and from a group of non-CF children with chronic bronchitis and bronchiectasis were compared.

\section{Materials and methods}

\section{Patients}

Three groups were studied. The first group included 25 $\mathrm{CF}$ children (14 males). In all patients, the diagnosis of CF was confirmed by a sweat chloride concentration $>60$ $\mathrm{MEq} \cdot \mathrm{L}^{-1}$. Over a 2 -month period, all children who visited the outpatient CF department or were admitted to the hospital for exacerbations were invited to participate in the study. The only criterion for eligibility was the ability to spontaneously produce an adequate volume of sputum. At the time of study, physical examination and chest radiographs were performed. The pulmonary function tests included determination of forced vital capacity (FVC), forced expiratory volume in one second (FEV1) and forced expiratory flow between 25 and $75 \%$ of FVC (FEF25-75), with values expressed as a percentage of predicted values according to height [16]. Oxygen saturation $\left(\mathrm{Sa}, \mathrm{O}_{2}\right)$ was recorded by means of pulse oximetry (Radiometer). The Shwachman-Kulkczycki score was calculated for each patient [17].

The second group included 10 (five males) non-CF children (with normal sweat chloride test results) with chronic bronchitis and diffuse bronchiectasis (DB). The diagnosis of bronchiectasis was based on history and accepted clinical and radiological criteria, and was confirmed via a computed tomography scan. Extensive investigations including complete immunological studies, as well as electronic analysis of the ciliary ultrastructure after fibroscopic biopsy, were performed. In this group, sputum was obtained spontaneously. At the time of study, physical examination, chest radiographs and pulmonary function tests were recorded.

The third (control) group included five young adults (mean age $24 \mathrm{yrs}$ ) from the medical staff. Indeed, for ethical reasons it was not possible to include control children and, therefore, sputum was obtained from nonsmoking adults with normal lung function and no history of lung disease. In this group, sputum was obtained after induction. Following administration of $200 \mu \mathrm{g}$ inhaled salbutamol, sputum induction was performed as described by Pizzichini et al. [18], with minor modifications. An aerosol of hypertonic saline $(\mathrm{NaCl} 5 \%)$ was generated through a mouthpiece by a De Vilbiss ultrasonic nebulizer (ultraneb 99) at maximal output $\left(6 \mathrm{~L} \cdot \mathrm{min}^{-1}\right)$. Every $5 \mathrm{~min}$, subjects were instructed to cough into a container. The nebulization was stopped after $20 \mathrm{~min}$, or earlier in cases of intolerance; the flow/ volume curve was then controlled.

In each case, informed consent was obtained, given either by the parents for the children or the subjects in the control group. The study was approved by the ethics committees of St. Antoine University Hospital, Paris, France.

\section{Preparation of sputum samples}

In the three groups, subjects were asked to rinse their mouth, swallow the water and blow their nose to minimize contamination with saliva and postnasal drip. The sputum was then collected in a sterile cup and processed immediately.

The sputum was first transferred to a Petri dish to select samples free of salivary contamination, as described by PIN et al. [19]. The volume of this selected sample was recorded and an equal volume of phosphate-buffered saline (PBS) $\left(0.14 \mathrm{M} \mathrm{NaCl}, 3 \mathrm{mM} \mathrm{KCl}, 8 \mathrm{mM} \mathrm{Na}_{2} \mathrm{HPO}_{4}, 15\right.$ $\left.\mathrm{mM} \mathrm{KH_{2 }} \mathrm{P}_{2} \mathrm{O}_{4}\right)$ added. The resulting suspension was agitated using a vortex mixer for $1 \mathrm{~min}$ and then centrifuged for $20 \mathrm{~min}$ at $8,800 \times g$. The supernatant was collected and stored in Eppendorf tubes at $-80^{\circ} \mathrm{C}$ for later analysis. The pellet was resuspended in four volumes of fresh dithiothreitol (Sigma) diluted to $0.1 \%$ with PBS and rocked for $15 \mathrm{~min}$. An additional four volumes of PBS were added and the solution rocked for a further $5 \mathrm{~min}$, The suspension was filtered through a $40 \mu \mathrm{m}$ nylon gauze (Falcon) to remove debris and then centrifuged for $10 \mathrm{~min}$ at $800 \times g$. The pellet was resuspended in a volume of $1-$ $20 \mathrm{~mL}$ PBS depending on macroscopic size in order to obtain a total cell count using a haemocytometer (Malassez chamber). The cell viability was evaluated by means of the trypan blue exclusion method. The cell suspension was adjusted to $10^{6}$ cells $\cdot \mathrm{mL}^{-1}$ and $75 \mu \mathrm{L}$ of cell suspension was placed into the cups of a Shandon II cytocentrifuge. Two coded cytospins were prepared at $500 \mathrm{rpm}$ for $5 \mathrm{~min}$. The slides were air-dried and stained using MayGrünwald-Giemsa. Sputum samples were used for cytokine measurement if they contained $<20 \%$ of squamous epithelial cells and cell viability was $>80 \%$, as proposed by Pizzichini et al. [18].

An aliquot of the sputum was used for quantitative bacterial cultures. Specific culture techniques were used to identify the common CF-related pathogens, Staphylococcus aureus, Haemophilus influenza and Pseudononas aeruginosa.

\section{Measurement of cytokine concentrations}

TNF- $\alpha$, IL-1 $\beta$, IL-6, IL-8, IL-10, IL-1ra and sTNFRII measurements were made using commercially available enzyme-linked immunosorbent assay kits according to the manufacturers' recommended protocols (Quantikine; R\&D Systems, Abingdon, UK). In a previous study, it was established that soluble receptors and $\alpha_{2}$-macroglobulin, known to combine with various cytokines, did not interfere with the measurements [20]. Cytokine concentrations were quantified by comparison with a standard curve generated using the appropriate recombinant human cytokine. Sensitivity and (dynamic range) were as follows: TNF- $\alpha$ : $4.4 \mathrm{pg} \cdot \mathrm{mL}^{-1}\left(15.6-1,000 \mathrm{pg} \cdot \mathrm{mL}^{-1}\right)$; IL-1 $3: 0.3 \mathrm{pg} \cdot \mathrm{mL}^{-1}$ $\left(3.9-250 \mathrm{pg} \cdot \mathrm{mL}^{-1}\right)$; IL-6: $0.7 \mathrm{pg} \cdot \mathrm{mL}^{-1}\left(3.13-300 \mathrm{pg} \cdot \mathrm{mL}^{-1}\right)$, IL-8: $10 \mathrm{pg} \cdot \mathrm{mL}^{-1}\left(31.2-2,000 \mathrm{pg} \cdot \mathrm{mL}^{-1}\right), \mathrm{IL}^{-10}: 2 \mathrm{pg} \cdot \mathrm{mL}^{-1}$ $\left(7.8-500 \mathrm{pg} \cdot \mathrm{mL}^{-1}\right)$, IL-1ra: $22 \mathrm{pg} \cdot \mathrm{mL}^{-1}(46.9-3,000$ $\left.\mathrm{pg} \cdot \mathrm{mL}^{-1}\right)$ and sTNFRII: $1 \mathrm{pg} \cdot \mathrm{mL}^{-1}\left(7.8-500 \mathrm{pg} \cdot \mathrm{mL}^{-1}\right)$. Samples with concentrations above the dynamic range of the assay were diluted and assayed again. 


\section{Results}

\section{Patients}

The main characteristics of the CF patients at the time of the study, together with the results of genetic analysis, are summarized in table 1. The median (range) age of this group was 12.0 yrs (6-19 yrs). The median (range) Shwachman-Kulkczycki score was 55 (20-95). Results of functional parameters, expressed as median (range) were as follows: FVC: 49\% (28-85\%); FEV1: 34\% (14-94\%); FEF25-75: 23\% (8-124\%); and $\mathrm{Sa}_{\mathrm{a}} \mathrm{O}_{2}: 94 \%$ (83-97\%). In addition to antibiotics, the main treatments routinely received by the patients included inhaled steroids, bron- chodilators, recombinant human deoxyribonuclease (rhDNase) and nasal ventilation (table 1). Based on evidence of acute pulmonary exacerbation defined using criteria including recent weight loss, increased cough, increased sputum production, change in sputum characteristics and recent decrease in pulmonary function, the CF group was separated into the following subgroups. Eight patients (patients 1-8) were considered to be stable. Seventeen patients (patients 9-25) were considered to have an acute pulmonary exacerbation. Among these 17 children, nine (patients 9-17) were included in the study just before the start of the antibiotic treatment; the other eight children (patients 18-25) were studied from 4-6 days after the start of antibiotic therapy.

Table 1. - Clinical characteristics of children with cystic fibrosis (CF)

\begin{tabular}{|c|c|c|c|c|c|c|c|c|c|c|}
\hline $\begin{array}{l}\text { Patient } \\
\text { No }\end{array}$ & Sex & $\begin{array}{l}\text { Age } \\
\text { yrs }\end{array}$ & $\begin{array}{c}\mathrm{CF} \\
\text { genotype }\end{array}$ & $\begin{array}{l}\text { Clinical } \\
\text { score }\end{array}$ & $\begin{array}{l}\mathrm{FVC} \\
\% \text { pred }\end{array}$ & $\begin{array}{l}\text { FEV1 } \\
\% \text { pred }\end{array}$ & $\begin{array}{c}\text { FEF25-75 } \\
\% \text { pred }\end{array}$ & $\mathrm{Sa}_{\mathrm{a}, \mathrm{O}_{2}}$ & $\begin{array}{c}\text { Sputum } \\
\text { bacteriology* }\end{array}$ & Treatment \\
\hline 1 & $\mathrm{~F}$ & 13 & $\Delta \mathrm{F} 508 / \mathrm{R} 560 \mathrm{~K}$ & 70 & 62 & 51 & 25 & 95 & $\begin{array}{l}10^{6} \mathrm{~S} . \text { aureus } \\
10^{8} \mathrm{P} \text {. aeruginosa }\end{array}$ & DNase, Inh St \\
\hline 2 & M & 11 & $\Delta \mathrm{F} 508 / \Delta \mathrm{F} 508$ & 60 & 43 & 34 & 17 & 90 & $\begin{array}{l}10^{7} P . \text { aeruginosa } \\
10^{8} \mathrm{~S} \text {. aureus }\end{array}$ & DNase \\
\hline 3 & M & 8 & $\Delta \mathrm{F} 508 / \Delta \mathrm{F} 508$ & 95 & 80 & 79 & 103 & 96 & $\begin{array}{l}10^{8} P . \text { aeruginosa } \\
10^{7} \mathrm{~S} \text {. aureus }\end{array}$ & - \\
\hline 4 & M & 17 & $\Delta \mathrm{F} 508 / \Delta \mathrm{F} 508$ & 40 & 32 & 14 & 8 & 83 & $\begin{array}{l}10^{4} \mathrm{P} \text {. aeruginosa } \\
10^{6} \mathrm{~S} \text {. aureus }\end{array}$ & $\begin{array}{c}\text { NV } \\
\text { DNase, Inh St, }\end{array}$ \\
\hline 5 & $\mathrm{~F}$ & 13 & $\Delta \mathrm{F} 508 / \Delta \mathrm{F} 508$ & 55 & 38 & 30 & 21 & 96 & $10^{10}$ B. cepacia & $\begin{array}{c}\text { Inh Bd } \\
\text { DNase, Inh St, }\end{array}$ \\
\hline 6 & $\mathrm{~F}$ & 18 & $\Delta \mathrm{F} 508 / \mathrm{R} 347 \mathrm{p}$ & 65 & 69 & 40 & 15 & 96 & $\begin{array}{l}\text { Mixed flora } \\
10^{5} S . \text { aureus }\end{array}$ & $\begin{array}{c}\text { Inh Bd } \\
\text { DNase, Inh St, }\end{array}$ \\
\hline 7 & M & 6 & $\Delta \mathrm{F} 508 / \Delta \mathrm{F} 508$ & 65 & ND & ND & ND & 96 & $10^{7} \mathrm{H}$. influenzae & Inh Bd \\
\hline 8 & $\mathrm{~F}$ & 11 & $\Delta \mathrm{F} 508 / \mathrm{NI}$ & 80 & 83 & 71 & 68 & 97 & $\begin{array}{l}10^{6} \text { A. xylosoxidans } \\
10^{9} \mathrm{P} . \text { aeruginosa }\end{array}$ & DNase \\
\hline 9 & $\mathrm{~F}$ & 13 & $\Delta \mathrm{F} 508 / \Delta \mathrm{I} 507$ & 75 & 85 & 94 & 124 & 96 & $10^{9}$ B. cepacia & DNase \\
\hline 10 & M & 8 & $\Delta \mathrm{F} 508 / \Delta \mathrm{F} 508$ & 50 & 71 & 64 & 42 & 96 & $10^{9}$ S. aureus & - \\
\hline 11 & M & 10 & $\Delta \mathrm{F} 508 / \mathrm{NI}$ & 45 & 46 & 32 & 25 & 92 & $\begin{array}{l}10^{7} P \text { aeruginosa } \\
10^{9} P \text { aeruginosa }\end{array}$ & DNase, Inh St \\
\hline 12 & $\mathrm{~F}$ & 18 & $\Delta \mathrm{F} 508 / \Delta \mathrm{F} 508$ & 55 & 33 & 26 & 17 & 92 & $10^{9}$ B. серасіа & DNase, Inh St \\
\hline 13 & $\mathrm{M}$ & 12 & NI & 20 & 28 & 28 & 29 & 89 & $\begin{array}{l}10^{\circ} \mathrm{P} . \text { aeruginosa } \\
10^{4} \mathrm{~S} . \text { aureus } \\
10^{9} \mathrm{H} \text {. influenzae }\end{array}$ & NV \\
\hline 14 & M & 16 & $\Delta \mathrm{F} 508 / \Delta \mathrm{F} 508$ & 65 & 54 & 28 & 34 & 94 & $\begin{array}{l}10^{6} \mathrm{P} \text {. aeruginosa } \\
10^{7} \mathrm{~S} \text {. aureus }\end{array}$ & $\begin{array}{l}\text { Inh St, Inh Bd } \\
\text { DNase, Inh St, }\end{array}$ \\
\hline 15 & M & 19 & 2711 delT/H1085R & 70 & 69 & 40 & 15 & 91 & $\begin{array}{l}10^{7} P \text {. aeruginosa } \\
10^{6} \mathrm{~S} \text {. aureus }\end{array}$ & Inh Bd \\
\hline 16 & $\mathrm{~F}$ & 11 & 3906 ins G/NI & 70 & 78 & 50 & 53 & 97 & $\begin{array}{l}10^{6} \mathrm{P} . \text { aeruginosa } \\
10^{7} \mathrm{~S} \text {. aureus }\end{array}$ & DNase \\
\hline 17 & M & 6 & $\Delta \mathrm{F} 508 / \Delta \mathrm{F} 508$ & 50 & ND & ND & ND & 93 & $10^{7} P$ aeruginosa & $\begin{array}{c}\text { DNase } \\
\text { DNase, Inh St, }\end{array}$ \\
\hline 18 & $\mathrm{~F}$ & 13 & $\Delta \mathrm{F} 508 / \Delta \mathrm{F} 508$ & 65 & 29 & 15 & 14 & 94 & $\begin{array}{l}10^{7} \text { B. cepacia } \\
10^{4} \text { S. aureus }\end{array}$ & $\begin{array}{c}\text { Inh Bd } \\
\text { NV, DNase, Oral St, }\end{array}$ \\
\hline 19 & M & 13 & $\mathrm{NI}$ & 35 & ND & ND & ND & 94 & $10^{10}$ A. xylosoxidans & Inh Bd \\
\hline 20 & M & 18 & $\Delta \mathrm{F} 508 / \Delta \mathrm{F} 508$ & 45 & 33 & 28 & 23 & 94 & $10^{6} \mathrm{~S}$. maltophilia & $\begin{array}{l}\text { Inh St, Inh Bd } \\
\text { DNase, Oral St, }\end{array}$ \\
\hline 21 & $\mathrm{~F}$ & 9 & $\Delta \mathrm{F} 508 / \Delta \mathrm{F} 508$ & 45 & 49 & 39 & 20 & 88 & $\begin{array}{l}10^{7} \mathrm{P} . \text { aeruginosa } \\
10^{8} \mathrm{~S} \text {. aureus }\end{array}$ & Inh Bd \\
\hline 22 & $\mathrm{~F}$ & 7 & $\Delta \mathrm{F} 508 / \Delta \mathrm{F} 508$ & 45 & ND & ND & ND & 93 & $10^{8} P$ aeruginosa & DNase \\
\hline 23 & $\mathrm{~F}$ & 10 & $\Delta \mathrm{F} 508 / \Delta \mathrm{F} 508$ & 40 & 34 & 20 & 14 & 91 & $\begin{array}{l}10^{2} \text { S. aureus } \\
10^{6} \text { S. aureus }\end{array}$ & Inh St, Inh Bd \\
\hline 24 & M & 16 & $\Delta \mathrm{F} 508 / \Delta \mathrm{F} 508$ & 45 & 39 & 29 & 12 & 93 & $10^{7}$ S. maltophilia & DNase \\
\hline 25 & $\mathrm{M}$ & 8 & $\Delta \mathrm{F} 508 / \Delta \mathrm{F} 508$ & 75 & 80 & 70 & 65 & 95 & $10^{6}$ S. maltophilia & DNase \\
\hline
\end{tabular}

*: number of cells per aliquot. Clinical score: Shwachman-Kulkczycki score. FVC: forced vital capacity; FEV1: forced expiratory volume in one second; FEF25-75: forced expiratory flow between 25 and $75 \%$ of FVC; $S_{a}, \mathrm{O}_{2}$ : arterial oxygen saturation; M: male; F: female; NI: not identified; ND: not determined; P. aeruginosa: Pseudomonas aeruginosa; S. aureus: Staphylococcus aureus; B. cepacia: Burkholderia cepacia; H. influenzae: Haemophilus influenzae; A. xylosoxidans: Alcaligenes xylosoxidans; S. maltophilia: Stenotrophomonas maltophilia; DNase: recombinant human deoxyribonucleaic; Inh: inhaled; St: steroids; NV: nasal ventilation; Bd: bronchodilators. 
Table 2. - Main characteristics of noncystic fibrosis children with diffuse bronchiectasis

\begin{tabular}{lcccccccc}
\hline $\begin{array}{l}\text { Patient } \\
\text { No. }\end{array}$ & Sex & $\begin{array}{c}\text { Age } \\
\text { yrs }\end{array}$ & Aetiology & $\begin{array}{c}\text { FVC } \\
\% \text { pred }\end{array}$ & $\begin{array}{c}\text { FEV1 } \\
\% \text { pred }\end{array}$ & $\begin{array}{c}\text { FEF25-75 } \\
\% \text { pred }\end{array}$ & $S_{a, O_{2}}$ & $\begin{array}{c}\text { Sputum } \\
\text { bacteriology }\end{array}$ \\
\hline 1 & M & 4 & CP & ND & ND & ND & 94 & Mixed flora \\
2 & M & 13 & CP & 52 & 37 & 15 & 95 & Mixed flora \\
3 & M & 14 & PCD & 87 & 92 & 100 & 97 & Predominance of H. influenzae \\
4 & M & 14 & PCD & 96 & 101 & 110 & 97 & Mixed flora \\
5 & F & 16 & PCD & 52 & 49 & 45 & 95 & Predominance of H. influenzae \\
6 & $\mathrm{~F}$ & 14 & PCD & 59 & 60 & 54 & 96 & Predominance of H. influenzae \\
7 & $\mathrm{~F}$ & 12 & PCD & 66 & 72 & 108 & 98 & Mixed flora \\
8 & $\mathrm{M}$ & 12 & PCD & 82 & 78 & 60 & 98 & Mixed flora \\
9 & $\mathrm{~F}$ & 10 & Unknown & 51 & 31 & 10 & 91 & Mixed flora \\
10 & $\mathrm{~F}$ & 6 & Unknown & ND & ND & ND & 86 & Mixed flora \\
\hline
\end{tabular}

FVC: forced vital capacity; FEV1: forced expiratory volume in one second; FEF25-75: forced expiratory flow between 25 and $75 \%$ of FVC; $\mathrm{S}_{\mathrm{a}} \mathrm{O}_{2}$ : arterial oxygen saturation; M: male; F: female; CP: childhood pneumonia; PCD: primary ciliary dyskinesia; ND: not determined; H. influenzae: Haemophilus influenzae.

The main characteristics of the children with DB are listed in table 2. The median (range) age of this group was 12.5 yrs (6-16 yrs). The primary cause of DB was documented in eight patients. In children 1 and 2 , the disease developed following a severe viral infection which occurred in the first year of life. In six children (patients 38 ), the diagnosis of primary ciliary dyskinesia was made based on clinical features and ultrastructural analysis of cilia. Results of immunological studies could not document immune deficiency. None of the children were in a period of pulmonary exacerbation and none were treated with intravenous antibiotics at the time of the study. Results of pulmonary function tests indicated alterations in lung function. The median (range) values were: FVC: 62.5\% (51-96\%); FEV1: 66\% (31-101\%); FEF25-75: $57 \%(10-110 \%) ; \mathrm{Sa}_{2} \mathrm{O}_{2}: 96 \%$ (86-98\%). Comparisons of the $\mathrm{CF}$ group and the non-CF group with DB indicated that the age of the patients at the time of the study was not different. Results of pulmonary function tests showed significant differences only for FEV1 $(p=0.02)$.

\section{Total and differential cell counts in the sputum samples}

The results obtained in the three groups are listed in table 3 . Total cell counts were significantly higher in the $\mathrm{CF}$ group and the non-CF group with $\mathrm{DB}$ compared to the control group. No significant difference could be documented between the two groups of CF patients and non-CF patients with DB regarding total cell count, percentage of squamous cells or of polymorphonuclear cells. A significant increase in the percentage of polymorphonuclear cells were found in the CF group and the non-CF group with $\mathrm{DB}$, when compared with the control group, and this was associated with a significant decrease in the percentage of macrophages.
Tumour necrosis factor- $\alpha$, interleukin-1 $\beta$ and interleukin-8 concentrations in the sputum samples

The concentrations of TNF- $\alpha$, IL- $1 \beta$ and IL- 8 obtained in the three groups are shown in figure 1. TNF- $\alpha$ levels (median; 5-95\% interval) were significantly increased in the CF group (448 $\mathrm{pg} \cdot \mathrm{mL}^{-1} ; 47-2,830 \mathrm{pg} \cdot \mathrm{mL}^{-1}$ ) compared to the control group $\left(9 \mathrm{pg} \cdot \mathrm{mL}^{-1} ; 0-23 \mathrm{pg} \cdot \mathrm{mL}^{-1}\right)$ $(p<0.001)$. TNF- $\alpha$ concentrations were also significantly increased in the group of non-CF patients with DB (918 $\left.\mathrm{pg} \cdot \mathrm{mL}^{-1} ; 80-12,600 \mathrm{pg} \cdot \mathrm{mL}^{-1}\right)$ compared to the control group $(\mathrm{p}<0.005)$. However, no significant differences could be found between the $\mathrm{CF}$ group and the non-CF group with $\mathrm{DB}(\mathrm{p}=0.07)$. In the $\mathrm{CF}$ group, lower levels of TNF- $\alpha$, were measured in the sputum of patients receiving inhaled steroids $(\mathrm{p}=0.04)$.

The highest levels of IL-1 $\beta$ (median; 5-95\% interval) were observed in the CF group $\left(12,220 \mathrm{pg} \cdot \mathrm{mL}^{-1} ; 2,800\right.$ $\left.32,000 \mathrm{pg} \cdot \mathrm{mL}^{-1}\right)$. These levels were significantly higher than the IL-1 $\beta$ levels measured in the non-CF group with DB $\left(1,170 \mathrm{pg} \cdot \mathrm{mL}^{-1} ; 400-13,000 \mathrm{pg} \cdot \mathrm{mL}^{-1}\right), \quad(\mathrm{p}<0.001)$. Statistical analysis also showed that IL-1 $\beta$ concentrations were significantly increased in the two groups of patients compared to the control group (269 $\mathrm{pg} \cdot \mathrm{mL}^{-1} ; 97-480$ $\left.\mathrm{pg} \cdot \mathrm{mL}^{-1}\right)(\mathrm{p}<0.001$ and $\mathrm{p}<0.005$ respectively $)$. When the levels of the pro-inflammatory cytokines TNF- $\alpha$ and IL-1 $\beta$ were compared in the three groups, a significant correlation between levels of TNF- $\alpha$ and IL- $1 \beta$ was only found in the non-CF group with DB ( $r=0.83 ; \mathrm{p}=0.03$ ).

The highest concentrations of IL- 8 (median; 5-95\% interval) were observed in the CF group $\left(71,000 \mathrm{pg} \cdot \mathrm{mL}^{-1}\right.$; $\left.10,400-180,800 \mathrm{pg} \cdot \mathrm{mL}^{-1}\right)$; the IL-8 levels measured in the non-CF group with $\mathrm{DB}$ were $18,000 \mathrm{pg} \cdot \mathrm{mL}^{-1} ; 6,800$ $131,000 \mathrm{pg} \cdot \mathrm{mL}^{-1}(\mathrm{p}=0.06)$. IL-8 levels in the two groups of

Table 3. - Total and differential cell counts in the sputum

\begin{tabular}{lccccc}
\hline & & \multicolumn{3}{c}{ Differential cell count \% } \\
\cline { 3 - 6 } Subjects & $\begin{array}{c}\text { Total cell count } \\
\left(10^{6} \text { cells } \mathrm{mL}^{-1}\right)\end{array}$ & $\mathrm{Sq}$ & PMN & LY & MA \\
\hline CF children & $7.8 \pm 5.0$ & $2.1 \pm 2.1$ & $94.1 \pm 2.8$ & $0.7 \pm 0.9$ & $2.3 \pm 1.4$ \\
Non-CF children with DB & $7.3 \pm 4.8$ & $1.3 \pm 1.8$ & $85.7 \pm 9.9$ & $0.1 \pm 0.2$ & $0.1 \pm 1.3$ \\
Control & $2.5 \pm 1.0$ & $6.5 \pm 2.4$ & $41.0 \pm 18.0$ & $0.1 \pm 0.3$ & $52.2 \pm 17.8$ \\
\hline
\end{tabular}

Sq: squamous cells; PMN: Polymorphonuclear cells; LY: lymphocytes; MA: macrophages; CF: cystic fibrosis; DB: diffuse bronchiectasis. 

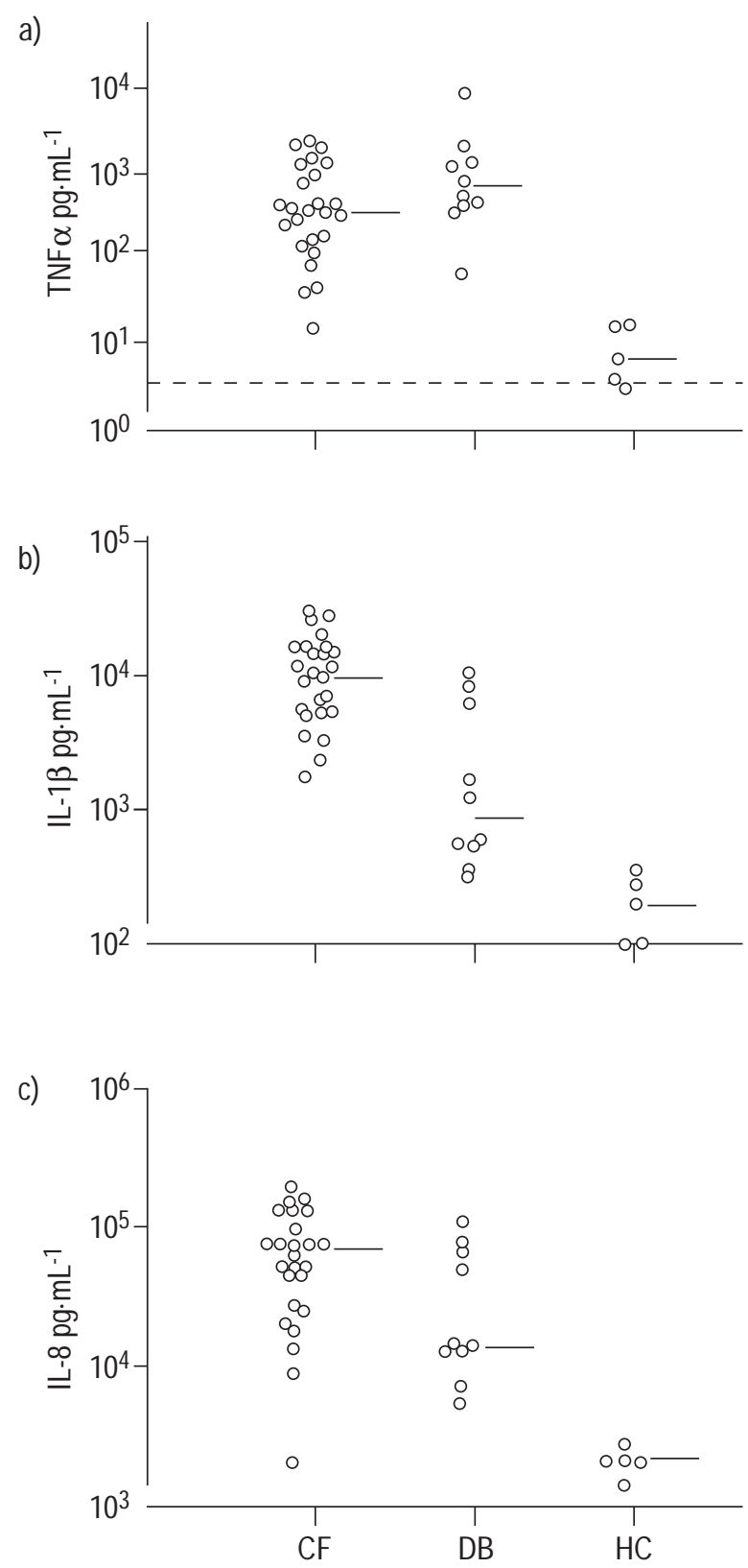

Fig. 1. - Concentrations of: a) tumour necrosis factor- $\alpha$ (TNF- $\alpha)$; b) interleukin (IL)-1 $\beta$; and c) IL-8 in sputum. The horizontal bars represent median values. - - - - limit of sensitivity of TNF- $\alpha$ assay. CF: cystic fibrosis; DB: diffuse bronchiectasis (non-CF); HC: healthy control.

patients were both higher than those in the control group $\left(2,800 \mathrm{pg} \cdot \mathrm{mL}^{-1} ; 1,800-3,600 \mathrm{pg} \cdot \mathrm{mL}^{-1}\right)(\mathrm{p}<0.005$ and $\mathrm{p}<$ 0.005 respectively). When the levels of IL-8 were compared to the levels of TNF- $\alpha$ and of IL- $1 \beta$ in the three groups, significant correlations between the increases in IL-8 and the increase in TNF- $\alpha$ and IL- $1 \beta$ were only found in the non$\mathrm{CF}$ group with DB ( $r=0.66 ; \mathrm{p}=0.03$ and $\mathrm{r}=0.87 ; \mathrm{p}=0.001)$.

Interleukin-6 and interleukin-10 concentrations in the sputum samples

The lowest levels of IL-6 (median; 5-95\% interval) were observed in the $\mathrm{CF}$ group $\left(26 \mathrm{pg} \cdot \mathrm{mL}^{-1} ; 12-110\right.$ pg. $\mathrm{mL}^{-1}$ ) (fig. 2). These levels were significantly different from the IL-6 levels measured in the non-CF group with DB $\left(620 \mathrm{pg} \cdot \mathrm{mL}^{-1} ; 150-3,300 \mathrm{pg} \cdot \mathrm{mL}^{-1}\right),(\mathrm{p}<0.001)$ and in the control group $\left(225 \mathrm{pg} \cdot \mathrm{mL}^{-1} ; 200-426 \mathrm{pg} \cdot \mathrm{mL}^{-1}\right),(\mathrm{p}<$ $0.001)$. When IL-6 concentrations in the non-CF group with $\mathrm{DB}$ and in the control group were compared, higher levels were found in the group of children with DB; however, the differences did not reach statistical significance $(\mathrm{p}=0.06)$.

Low levels of IL-10 (median; 5-95\% interval) were also found in the CF group (24 pg. $\mathrm{mL}^{-1} ; 0-228 \mathrm{pg} \cdot \mathrm{mL}^{-1}$ ) (fig. $2)$. These levels were significantly lower than those in the control group (45 $\left.\mathrm{pg} \cdot \mathrm{mL}^{-1} ; 32-76 \mathrm{pg} \cdot \mathrm{mL}^{-1}\right)(\mathrm{p}=0.02)$; however, comparison with the concentrations found in the non-CF group with DB $\left(177 \mathrm{pg} \cdot \mathrm{mL}^{-1} ; 0-815 \mathrm{pg} \cdot \mathrm{mL}^{-1}\right)$ did not reach statistical significance.

Interleukin-1 receptor antagonist and soluble tumour necrosis factor receptor II concentrations in the sputum samples

The concentrations of IL-1ra and sTNFRII obtained in the three groups are shown in figure 3 . The highest levels of IL-1 ra (median; 5-95\% interval) were measured in the CF group $\left(94,000 \mathrm{pg} \cdot \mathrm{mL}^{-1} ; 13,500-392,000 \mathrm{pg} \cdot \mathrm{mL}^{-1}\right)$. These levels were significantly higher than the levels measured in the control group $\left(33,300 \mathrm{pg} \cdot \mathrm{mL}^{-1} ; 16,000\right.$ $\left.150,000 \mathrm{pg} \cdot \mathrm{mL}^{-1}\right)(\mathrm{p}=0.004)$ and in the non-CF group with DB $\left(31,000 \mathrm{pg} \cdot \mathrm{mL}^{-1} ; 23,000-71,000 \mathrm{pg} \cdot \mathrm{mL}^{-1}\right)$ $(p=0.004)$. No statistically significant difference could be observed between the non-CF group with $\mathrm{DB}$ and the control group $(\mathrm{p}=0.8)$. No correlations could be documented between the levels of IL-1ra and of IL-1 $\beta$ in the three groups.

Lower levels of STNFRII (median; 5-95\% interval) were found in the CF group $\left(2,100 \mathrm{pg} \cdot \mathrm{mL}^{-1} ; 332-9,000\right.$ $\left.\mathrm{pg} \cdot \mathrm{mL}^{-1}\right)$ than in the non-CF group with DB $(4,900$ $\left.\mathrm{pg} \cdot \mathrm{mL}^{-1} ; 1,500-10,000 \mathrm{pg} \cdot \mathrm{mL}^{-1}\right)(\mathrm{p}<0.01)$. Also, in these two groups of patients, sTNFRII levels were higher than in the control group $\left(440 \mathrm{pg} \cdot \mathrm{mL}^{-1} ; 110-1,200 \mathrm{pg} \cdot \mathrm{mL}^{-1}\right)$ $(p<0.01$ and $p<0.005$ respectively). A correlation between the increase in sTNFRII concentrations and the increase in TNF- $\alpha$ concentrations was found in the CF group $(r=0.5$; $\mathrm{p}=0.01$ ).

\section{Analysis of cytokine results in the cystic fibrosis group}

No relationship could be found between the various cytokine concentrations and either the clinical score or the functional parameters (FVC, FEV1, FEF25-75 and $\mathrm{Sa}_{\mathrm{a}} \mathrm{O}_{2}$ ). In addition, no differences could be found when the data were analysed based on the absence or presence of $P$. aeruginosa in the sputum.

When the patients were separated into the three subgroups defined above (i.e. stable patients, patients with exacerbation included prior to antibiotic treatment, patients with exacerbation included after start of treatment), no significant differences in the levels of TNF- $\alpha$, IL-6, IL-8 IL-10, IL-1ra and sTNFRII could be found (fig. 4). By contrast, analysis of IL-1 $\beta$ concentrations revealed levels significantly higher in the patients with exacerbation prior to treatment than in the stable patients $(\mathrm{p}=0.02)$ and in the children with exacerbation included after start of treatment ( $p=0.002$ ) (fig. 4). When the treatments received by 

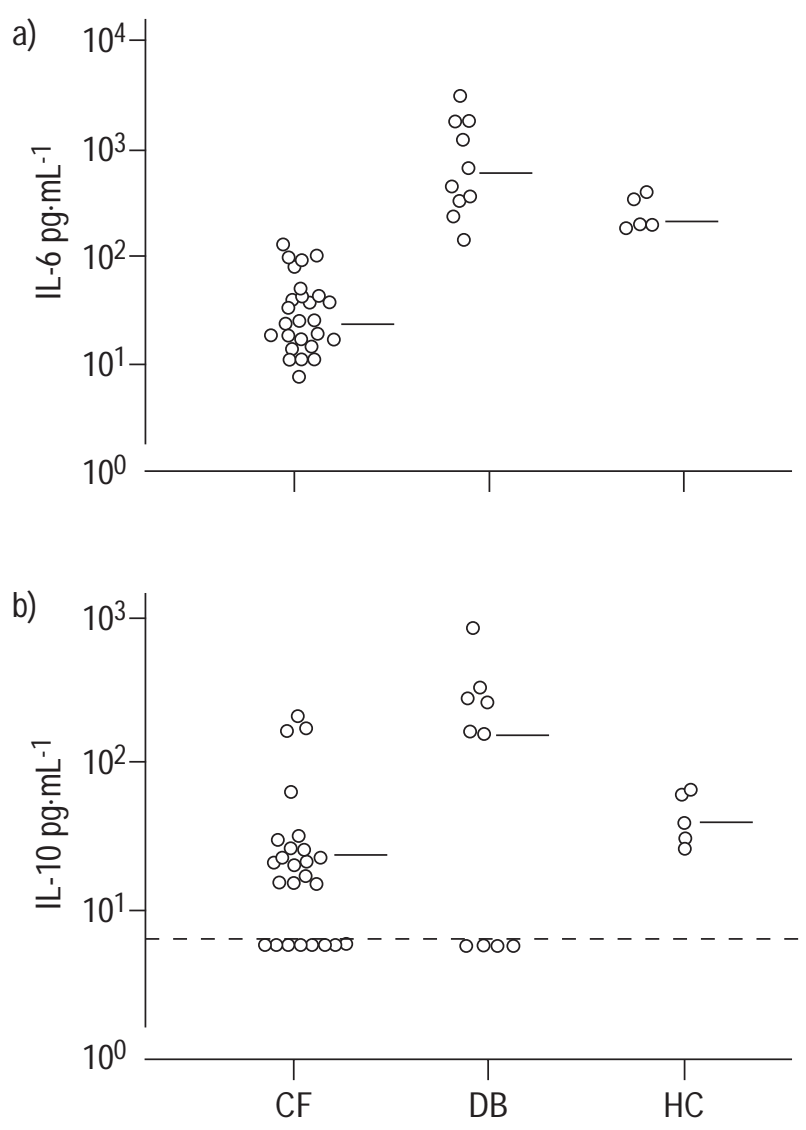

Fig. 2. - Concentrations of: a) interleukin (IL)-6; and b) IL-10 in sputum. The horizontal bars represent median values. - - - : limit of senstivity of IL-10 assay. CF: cystic fibrosis; DB diffuse bronchiectasis (non-CF); HC: healthy control.

the children were considered, no differences could be observed between the patients not treated or treated with bronchodilators or with rhDNase. In patients receiving inhaled steroids, the only difference observed was for TNF- $\alpha$, as mentioned above: lower levels of TNF- $\alpha$ were measured in the sputum of those patients $(\mathrm{p}=0.04)$.

\section{Discussion}

The goal of the present work was to characterize the cytokine burden in the airways of children with CF. Results were analysed based on clinical, bacteriological and functional parameters, and were compared to cytokine levels in the sputum of non-CF children with DB. To the authors' knowledge, the data reported herein represent the first report on the levels of a large number of cytokines in the sputum of $\mathrm{CF}$ and non-CF children with chronic inflammatory airway disease. Elevated concentrations of the proinflammatory cytokines TNF- $\alpha$, IL- $1 \beta$ and IL- 8 were found in the two groups of patients, with significantly higher amounts of IL-1 $\beta$ in CF children. Analysis of natural anti-inflammatory cytokines (IL-1 ra and sTNFRII) showed distinct patterns with elevated levels of both inhibitors in CF patients, whereas only sTNFRII was found to be increased in children with non-CF chronic bronchitis. The concentrations of IL-10 were low in the CF group. The most striking findings were the IL- 6 concentrations. In CF patients, the concentrations of IL- 6 in the airways were extremely low. In contrast, significantly increased IL-6 levels were found in non-CF children with chronic bronchitis.

In order to determine whether changes in sputum cytokine levels could be influenced by disease progression, different markers of lung disease gravity were studied. The only difference observed was the presence of higher levels of IL-1 $\beta$ in the sputum of children with acute exacerbation just before the start of treatment. A significant reduction in IL-1 $\beta$ concentration was observed in the treated patients. Comparisons with other reports in the literature are difficult as the populations included in the various studies are different in terms of age, clinical and functional status, therapeutic protocols and cytokine reference values. SALvA et al. [15] studied TNF- $\alpha$, IL-8 and soluble intercellular adhesion molecule- 1 in the sputum of 40 patients: they did not find any relationship with lung function or with clinical status. KRONBORG et al. [13] also reported no significant correlation between IL- $1 \beta$ concentrations in sputum and pulmonary function. In contrast, GreAlly et al. [10], in their study of TNF- $\alpha$ in sputum from $16 \mathrm{CF}$ children, showed an inverse relationship between TNF- $\alpha$ and FEV1, and DEAN et al. [9] reported a relationship between IL-8 concentrations and clinical score. In the present work, the question of changes in cytokine levels in relation to treatments received by the patients has also been addressed. In patients receiving inhaled steroids, an effect on TNF- $\alpha$ was observed. However, no modifications could be observed with rhDNase.

The present study focused not only on the proinflammatory molecules but also on the molecules whose function would be to downregulate the inflammatory response. It has been proposed that downregulation of IL-10 production in CF patients may represent a critical event in excessive inflammatory response in the airways. BONFIELD et al. [7] reported a series of experiments indicating that the epithelial lining fluid of CF patients contained less IL10 than did that of control subjects. They also showed that normal bronchial epithelial cells constitutively produced IL-10, which was downregulated in CF cells [8]. In the present study, similar results were obtained as the concentrations of IL-10 in CF children were found to be significantly lower than those of the control groups. However, although the lowest levels of IL-10 were found in sputum from $\mathrm{CF}$ patients, comparisons with the non-CF group of patients did not reach statistical significance.

One of the most striking results of the present work is the very low level of IL-6 measured in the sputum of the $\mathrm{CF}$ population. This was observed independently of the clinical, bacteriological or functional status of the patients. The low concentrations of IL-6 in CF children was most surprising as the concentrations of IL- 6 in the airways of non-CF children with DB was significantly increased compared to control values. It is important to note that the IL-6 results documented herein in patients without $\mathrm{CF}$ are consistent with the high levels of IL-6 measured in BAL fluid in a number of lung inflammatory diseases such as pneumonia, acute respiratory distress syndrome, asthma and bronchodysplasia [21, 22]. IL-6 has been less studied in sputum. FAHY et al. [23] reported low IL-6 levels in sputum from $\mathrm{CF}$ patients compared to that from asthmatic patients. Ruef et al. [24] were unable to find any biological activity of IL-6 in CF sputum. KRONBORG et al. [13] measured IL-6 levels in sputum from CF patients, 

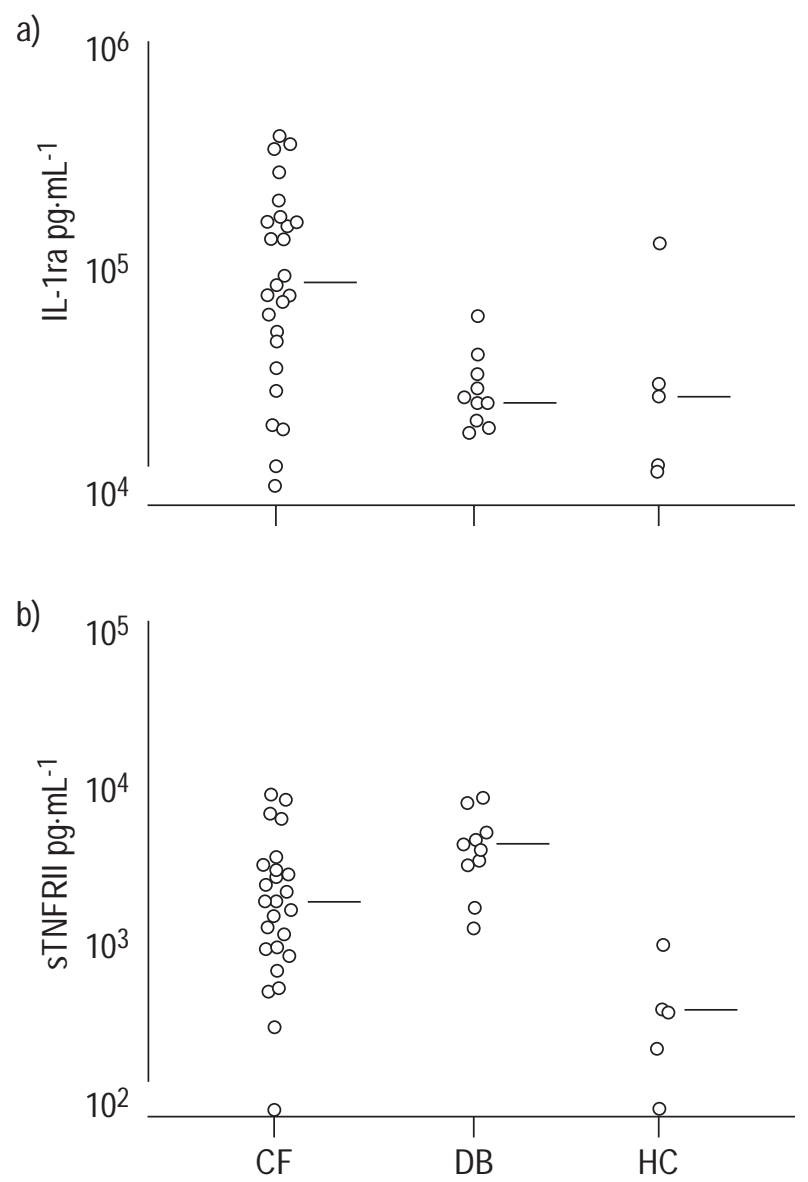

Fig. 3. - Concentrations of: a) interleukin-1 receptor antagonist (IL1ra); and b) soluble tumour necrosis factor receptor II (sTNFRII) in serum. Horizontal bars represent median values. CF: cystic fibrosis; DB diffuse bronchiectasis (non-CF); HC: healthy control.

but their data are difficult to analyse because of the absence of reference values. Recently, NixON et al. [25] reported IL- 6 data from the blood and the sputum of CF adults. They did not have a control group for their sputum experiments, but the IL-6 levels they found seemed to be in the range of the CF values reported herein. The low levels of IL-6 in CF may be explained by a decrease in its production (possibly in relation to the underlying disease), and/or with an increase in its degradation by local proteases. Against this latter hypothesis is the study of BONFIELD et al. [7], showing no changes after a 30-min incubation at room temperature of IL-6-containing samples in the presence of proteases. Recently, NIXON et al. [25] performed spiking experiments with exogenous IL-6 added to CF sputum and obtained a recovery of $98 \%$. In contrast, RUEF et al. [24] reported a decrease in IL-6 bioactivity when recombinant IL-6 was incubated with high concentrations of neutrophil elastase for $24 \mathrm{~h}$ at $37^{\circ} \mathrm{C}$. Clearly, studies are required to document the mechanisms leading to decreased IL-6 levels in sputum from CF patients.

The role of IL-6 during inflammation processes has recently been reconsidered and several studies suggest that IL-6 can display a number of anti-inflammatory effects. The mechanisms underlying the anti-inflammatory actions of IL-6 are likely to be several and include regulation of

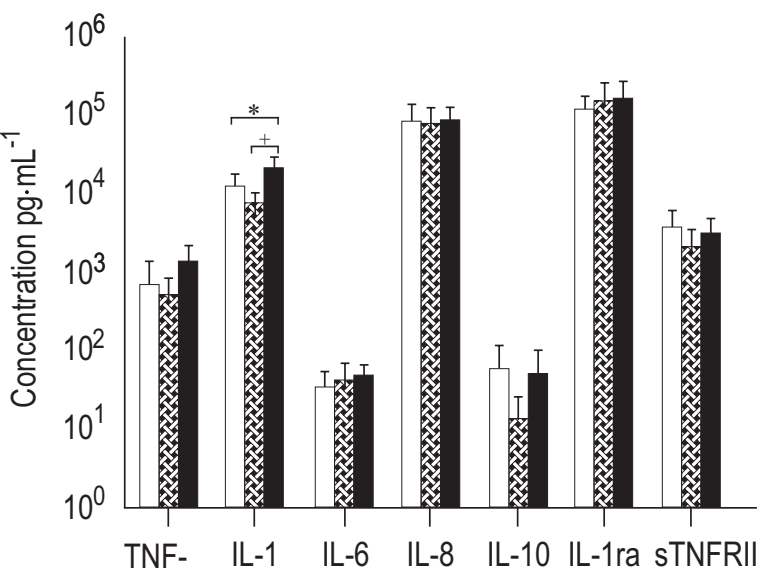

Fig. 4. - Sputum cytokine concentrations in the three groups of cystic fibrosis (CF) patients. Based on criteria detailed in the Patients section of the Results, the $25 \mathrm{CF}$ children were separated into three subgroups: eight stable patients ( $\square$ ); eight patients receiving antibiotic treatment (㸚); and nine patients experiencing acute pulmonary exacerbation ( $\square$ ). Data are presented as mean \pm SEM. TNF- $\alpha$ : tumour necrosis factor- $\alpha$; IL: interleukin; IL-1ra: IL-1 receptor antagonist; sTNFRII: soluble tumour necrosis factor receptor II.

acute phase protein (APP) expression. IL-6 induces, in the liver, the synthesis of a number of APPs such as C-reactive protein and $\alpha_{1}$-antitrypsin. The function of these plasmatic proteins is to reach inflammatory sites and locally to limit the actions of inflammatory cells, including human neutrophil superoxide production [26]. IL-6 plays a role in the resolution of acute and chronic inflammatory processes via the induction of glucocorticoid release as well as via induction of natural antagonists of IL-1 $\beta$ and TNF- $\alpha$ [27]. Studies on IL-6 knockout (IL-6 -/-) mice provided important information on the role of IL-6 during inflammation and infections. In IL-6 -/- mice, induction of skin abscesses by turpentine was characterized by absence of fever, weight loss and hypoglycemia and an increase in the concentration of plasmatic C-reactive protein, events normally observed in wild-type animals $[28,29]$. Infections with different pathogens in IL-6 -/- mice led to an enhancement of infectious dissemination with multiple organ abscesses, mainly comprised of polymorphonuclear cells, despite the absence of plasmatic hyperleukocytosis $[30,31]$. Interestingly, studies in $\mathrm{CF}$ patients have also shown that, even during exacerbation periods, plasmatic elevation of C-reactive protein as well as of other APPs was not frequent [32]. Moreover, in their recent report, NIXON et al. [25] documented circulating levels of IL-6 in the range of $10 \mathrm{pg} \cdot \mathrm{mL}^{-1}$ in $\mathrm{CF}$ patients. These levels were dramatically lower than those usually reported in various diseases with acute inflammation. Taken together, these data give support to altered IL-6 regulation in CF. Impairment of IL- 6 functions may represent an important component of the excessive inflammatory response observed in this disease.

To conclude, the present results provide information on the particularities of the inflammatory response in cystic fibrosis patients by comparing data with those obtained in noncystic fibrosis patients with diffuse bronchiectasis. Studies are currently being pursued to characterize the mechanisms involved and the possible link with the altered cystic fibrosis transmembrane conductance regulator gene expression in cystic fibrosis patients. 
Acknowledgements. The authors thank M. Miesch for technical assistance and C. Marie for stimulating discussion.

\section{References}

1. Davis PB, Drumm M, Konstan MW. Cystic fibrosis. Am J Respir Crit Care Med 1996; 154: 1229-1256.

2. Konstan MW, Berger M. Infection and inflammation of the lung in cystic fibrosis. In: PB Davis, ed. Cystic Fibrosis. New York, Marcel Dekker, 1993; pp. 219-276.

3. Khan TZ, Wagener JS, Bost T, Martinez J, Accurso FJ, Riches DW. Early pulmonary inflammation in infants with cystic fibrosis. Am J Respir Crit Care Med 1995; 151: 1075-1082.

4. Balough K, McCubbin M, Weinberger M, Smits W, Arhens R, Fick R. The relationship between infection and inflammation in the early stages of lung disease from cystic fibrosis. Pediatr Pulmonol 1995; 20: 63-70.

5. Konstan MW, Hilliard KA, Norvell TM, Berger M. Bronchoalveolar lavage findings in cystic fibrosis patients with stable, clinically mild lung disease suggest ongoing infection and inflammation. Am J Respir Crit Care Med 1994; 150: 448-454.

6. Konstan M, Berger M. Current understanding of the inflammatory process in cystic fibrosis: onset and etiology. Pediatr Pulmonol 1997; 24: 137-142.

7. Bonfield TL, Panuska JR, Konstan M, et al. Inflammatory cytokines in cystic fibrosis lungs. Am J Respir Crit Care Med 1995; 152: 2111-2118.

8. Bonfield TL, Konstan MW, Burfeind P, Panuska JR, Hilliard JB, Berger M. Normal bronchial epithelial cells constitutively produce the anti-inflammatory cytokine interleukin-10, which is downregulated in cystic fibrosis. Am J Respir Cell Mol Biol 1995; 13: 257-261.

9. Dean TP, Dai Y, Shute JK, Church MK, Warner JO Interleukin-8 concentrations are elevated in bronchoalveolar lavage, sputum, and sera of children with cystic fibrosis. Pediatr Res 1993; 34: 159-161.

10. Greally P, Hussein MJ, Cook AJ, Sampson AP, Piper PJ, Price JF. Sputum tumor necrosis factor- $\alpha$ and leukotriene concentrations in cystic fibrosis. Arch Dis Child 1993; 68: 389-392.

11. Kelly N, Clee S, Nakielna B. Bioactive tumor necrosis factor in the sputa of cystic fibrosis patients. Clin Diagn Lab Immunol 1995; 2: 499-502.

12. Koller DY, Nething I, Otto J, Urbanek R, Eichler I. Cytokine concentrations in sputum from patients with cystic fibrosis and their relation to eosinophil activity. $\mathrm{Am}$ J Respir Crit Care Med 1997; 155: 1050-1054.

13. Kronborg G, Hansen MB, Svenson M, Fomsgaard A, Hoiby $\mathrm{N}$, Bendtzen $\mathrm{K}$. Cytokines in sputum and serum from patients with cystic fibrosis and chronic Pseudomonas aeruginosa infection as markers of destructive inflammation in the lungs. Pediatr Pulmonol 1993; 15: 292-297.

14. Noah TL, Black HR, Cheng PW, Wood RE, Leigh MW. Nasal and bronchoalveolar lavage fluid cytokines in early cystic fibrosis. $J$ Infect Dis 1997; 175: 638-647.

15. Salva PS, Doyle NA, Graham L, Eigen H, Doerschuk CM. TNF- $\alpha$ IL-8, soluble ICAM-1, and neutrophils in sputum of cystic fibrosis patients. Pediatr Pulmonol 1996; 21: 11-19.
16. Bellon G, So S, Brun J, Adeleine P, Gilly R. Flow-volume curve in children in health and disease. Bull Europ Physiopath Resp 1982; 18: 705-715.

17. Shwachman H, Kulczycki L. Long-term study of 105 patients with cystic fibrosis. Am J Dis Child 1958; 96: 615 .

18. Pizzichini E, Pizzichini MMM, Efthimiadis A, et al. Indices of airway inflammation in induced sputum: reproducibility and validity of cell and fluid-phase measurements. Am J Respir Crit Care Med 1996; 154: 308-317.

19. Pin I, Gibson PJ, Kolendowicz R, et al. Use of induced sputum cells counts to investigate airway inflammation in asthma. Thorax 1992; 47: 25-29.

20. Ledur A, Fitting C, David B, Hamberger C, Cavaillon J$\mathrm{M}$. Variable estimates of cytokine levels produced by commercial ELISA kits: results using international cytokine standards. J Immunol Methods 1995; 186: 171-179.

21. Dehoux MS, Boutten A, Ostinelli J, et al. Compartmentalized cytokine production within the human lung in unilateral pneumonia. Am J Respir Crit Care Med 1994; 150: 710-716.

22. Virchow JC, Kroegel C, Walker C, Matthys H. Inflammatory determinants of asthma severity: mediator and cellular changes in bronchoalveolar lavage fluid of patients with severe asthma. J Allergy Clin Immunol 1996; 98: S27-S33.

23. Fahy JV, Kim KW, Liu J, Boushey HA. Prominent neutrophilic inflammation in sputum from subjects with asthma exacerbation. $J$ Allergy Clin Immunol 1995; 95: 843-852.

24. Ruef CD, Jefferson DM, Schlegel-Haueter SE, Suter S. Regulation of cytokine secretion by cystic fibrosis airway epithelial cells. Eur Respir J 1993; 6: 1429-1436.

25. Nixon L, Yung B, Bel S, Elborn J, Shale D. Circulating immunoreactive interleukin-6 in cystic fibrosis. $A m J$ Respir Crit Care Med 1998; 157: 1764-1769.

26. Heuertz RM, Ahmed N, Webster RO. Peptides derived from C-reactive protein inhibit neutrophils alveolitis. $J$ Immunol 1996; 156: 3412-3417.

27. Tilg H, Dinarello CA, Mier JW. IL-6 and APPs: antiinflammatory and immunosuppressive mediators. Iтmunol Today 1997; 18: 428-432.

28. Kozak W, Poli V, Soszynski D, Conn CA, Leon LR, Kluger MJ. Sickness behavior in mice deficient in interleukin-6 during turpentine abscess and influenza pneumonitis. Am J Physiol 1997; 272: R621-R630.

29. Fattori E, Capelletti M, Costa P, et al. Defective inflammatory response in interleukin 6-deficient mice. $J$ Exp Med 1994; 180: 1243-1250.

30. Dalrymple SA, Lucian LA, Slattery R, et al. Interleukin-6 deficient mice are highly susceptible to Listeria monocytogenes infection: Correlation with inefficient neutrophilia. Infect Immun 1995; 63: 2262-2268.

31. Dalrymple SA, Slattery R, Aud DM, Krishna M, Lucian LA, Murray R. Interleukin-6 is required for a protective immune response to systemic Escherichia coli infection. Infect Immun 1996; 64: 3231-3235.

32. Valetta EA, Rigo A, Bonazzi L, Zanolla L, Mastella G. Modification of some markers of inflammation during treatment for acute respiratory exacerbation in cystic fibrosis. Acta Paediatr 1992; 81: 227-230. 